Ciencias

Veterinarias
Rev. Ciencias Veterinarias, Vol. 37, N 3, [6-7], E-ISSN: 2215-4507

First Symposium on Regenerative Medicine and Nanotechnology, Costa Rica 2019 DOI: https://doi.org/10.15359/rcv.37-3.1

URL: http://www.revistas.una.ac.cr/index.php/veterinaria/index

\title{
Regenerative Medicine: where their origin makes species meet
}

\section{Medicina Regenerativa: donde su origen hace que las especies se encuentren}

Jos Malda ${ }^{1}$

1 Department of Orthopedics University Medical Center Utrecht, The Netherlands.

1 Department of Equine Sciences Faculty of Veterinary Medicine, Utrecht University, The Netherlands.

E-mail: j.malda@umcutrecht.nl

\begin{abstract}
The articular cartilage of joints serves diverse functions, including absorbing shock, transmitting force, and enabling low-friction joint motion. Regeneration of articular cartilage defects remains, however, a significant challenge in both human and veterinary orthopaedic practice. Ex vivo and in vivo models play a crucial role in translating novel potential regenerative treatments from bench to bedside. However, in view of the predictive power of these models and the One Medicine concept that proclaim that there should be no dividing lines between human and animal medicine to learn, it is important to understand the similarities as well as differences in the cartilage tissue between species. To this aim, osteochondral cores of the femoral condyles were studied in 58 different mammalian species ranging from mouse to elephant. Interestingly, while biochemical composition remained relatively constant, cartilage thickness and cellularity were similar underscoring the importance of the equine species as a model for human orthopaedic interventions.

Nevertheless, political ambition and societal pressure are now asking for a drastically reduction of animal experimentation and have further spiked the development of more predictive in vitro and ex vivo models. In addition to a range of more sophisticated in vitro assays, this has now also provided an ex vivo osteochondral defect model that can be generated based on equine donor tissue. Although such models better represent the situation in the native tissue and can be used to assess (osteo)chondral repair strategies, they still lack some important aspects of the in vivo (patho)physiological (inflammatory) environment, as well as the exposure to mechanical loading. This illustrates the challenges that we still face in translating these novel approaches from bench to bedside.
\end{abstract}

\section{References}

Malda, J., Benders, K.E., Klein, T.J., de Grauw, J.C., Kik, M.J., Hutmacher, D.W., Saris, D.B., van Weeren, P.R. \& Dhert, W.J. 2012. Comparative study of depth-dependent characteristics of equine and human osteochondral tissue from the medial and lateral femoral condyles. Osteoarthr. Cartilage 20(10):1147-1151. DOI: 10.1016/j.joca.2012.06.005 
Ciencias

Veterinarias

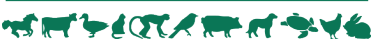

Rev. Ciencias Veterinarias, Vol. 37, N 3, [6-7], E-ISSN: 2215-4507

First Symposium on Regenerative Medicine and Nanotechnology, Costa Rica 2019 DOI: https://doi.org/10.15359/rcv.37-3.1 URL: http://www.revistas.una.ac.cr/index.php/veterinaria/index

Malda, J., de Grauw, J.C., Benders, K.E., Kik, M.J., van de Lest, C.H., Creemers, L.B., Dhert, W.J. \& van Weeren, P.R. 2013. Of mice, men and elephants: the relation between articular cartilage thickness and body mass. PLoS One 8(2): e57683. DOI: 10.1371/journal.pone.0057683

Mouser, V.H., Dautzenberg, N.M., Levato, R., van Rijen M.H.P., Dhert, W.J.A., Malda J., Gawlitta, D. 2018. Ex vivo model unravelling cell distribution effect in hydrogels for cartilage repair. ALTEX 35(1): 65-76. doi: 10.14573/altex.1704171 